\title{
Caesarean Myomectomy As Safe And Feasible Procedure: Prospective Study of 6 Cases.
}

\author{
Apurvashriramthakare ${ }^{1}, \mathrm{R}$ K Praneshwari Devi ${ }^{2}$, Pangertemsu $^{3}$, Pushpal \\ Chowdhury ${ }^{4}$, G. Deepthambiga ${ }^{5}$, Apekshasateesh Kudtarkar ${ }^{6}$. \\ Postgraduate Student $t^{1}$, Associate Professor ${ }^{2}$, Senior Resident ${ }^{3}$, Postgradute Student ${ }^{4,5,6}$. \\ Department Of Obstetrics And Gynaecology, RIMS, Imphal, Manipur, India.
}

\begin{abstract}
Myomectomy at the time of caesarean delivery has been discouraged because of the risk of intractable haemorrhage and increased postoperative morbidity. A prospective study was conductedin a tertiary care teaching hospital in Manipur, India which included 6 pregnant women with uterine fibroids who underwent myomectomy during caesarean section.Type of Caesarean section, size and location of the fibroids, blood loss, postoperative morbidity, and neonatal outcome was studied. Total 12 fibroids were removed, with size varying from 5-13 cm. None of the patients required blood transfusion or hysterectomy. Myomectomy added 15-20 minutes to the operating time and there were no significant postoperative complications or prolongation of hospital stay. Neonatal outcome was good in all the patients.The message is that it's time to recommend caesarean myomectomy with adequate expertise, proper patient selection and effective haemostatic measures, which could also have a positive bearing on future reproductive outcomes.
\end{abstract}

Keywords: Caesarean, haemorrhage, hysterectomy, myomectomy.

\section{Introduction}

Myomas are benign monoclonal tumors of smooth muscle cells of the myometrium. Their incidence among women is generally cited as $20-25 \%$, but has been shown to be as high as $70-80 \%$ by sonographic and histologic studies.[1]The incidence of myoma associated with pregnancy is reported as $0.3-5 \%$, with rising incidence owing to delayed child bearing age and improved diagnostic techniques.[2-5]Traditional beliefs advocated avoidance of concurrent myomectomy at the time of a Caesarean section has due to fears of potential complications, most importantly intractable haemorrhage leading to hysterectomy and subsequent fertility issues.[6]However, a number of recent studies have favoured Caesarean myomectomy.[3,7-18]

Though myomectomy during caesarean is still condemned, caesarean myomectomy is now favoured in selected cases and experienced hands. The former has concerns such as risk of surgery and anaesthesia in antenatal period, postoperative adhesions, increased likelihood of subsequent caesarean at the time of delivery including a rare risk of myomectomy scar rupture, increased cost and discomfort owing to two surgeries in a short span of time. Myomectomy at the time of caesarean is feasible owing to the increased looseness of the capsule. Morever postpartum uterine contraction helps in further haemostasis. Concurrent myomectomy during caesarean prevents the added morbidity of a separate procedure for removal of fibroids in future, avoids upper segment uterine section, adhesion formation, allows trail for normal labour in future pregnancy and justifies the cost effectiveness. No significant difference has been observed in the haemoglobin change, incidence of post operative complications and length of hospital stay as compared to other post caesarean patients. ${ }^{17}$ Fertility and obstetric outcome after caesarean myomectomyremain unaffected.[19]Above all preservation of an organ without compromise of its function is definitely a superior surgical achievement; hence, Caesarean myomectomy must be considered by experienced obstetricians wherever feasible.

We present a series of 6 cases of pregnancy with myoma, where myomectomy was performed during Caesarean section. A brief discussion of antenatal course, perioperative management and postoperative morbidity of the included cases is presented.

\section{Methods}

A prospective study of 6patients withmyomas complicating pregnancy who underwent myomectomy at the time of Caesarean section at Regional Institute of Medical Sciences, a tertiary teaching hospital, Imphal, Manipur between May 2015 to March 2016 was performed. Relevant patients' information pertaining to age, parity, antenatal course, type of Caesarean section, size and location of the fibroids, blood loss, postoperative morbidity, and neonatal outcome was collected. All women included in the study fulfilled the following criteria: 1)pregnancy with fibroid diagnosed by antenatal ultrasound or at surgery; 2) delivery by Caesarean section; 3 ) no other surgical procedure at Caesarean other than myomectomy, and 4) no pre-existing coagulopathy. Informed consent was obtained from all patients preoperatively. 
Myomectomy was performed using the conventional enucleation technique followed by obliteration the dead space in two to three layers using interrupted 1-0 Vicryl sutures. Myomectomy followed the delivery of the baby, except in a case where anterior wall myomawas encroaching the proposed LSCS incision Fig 1.
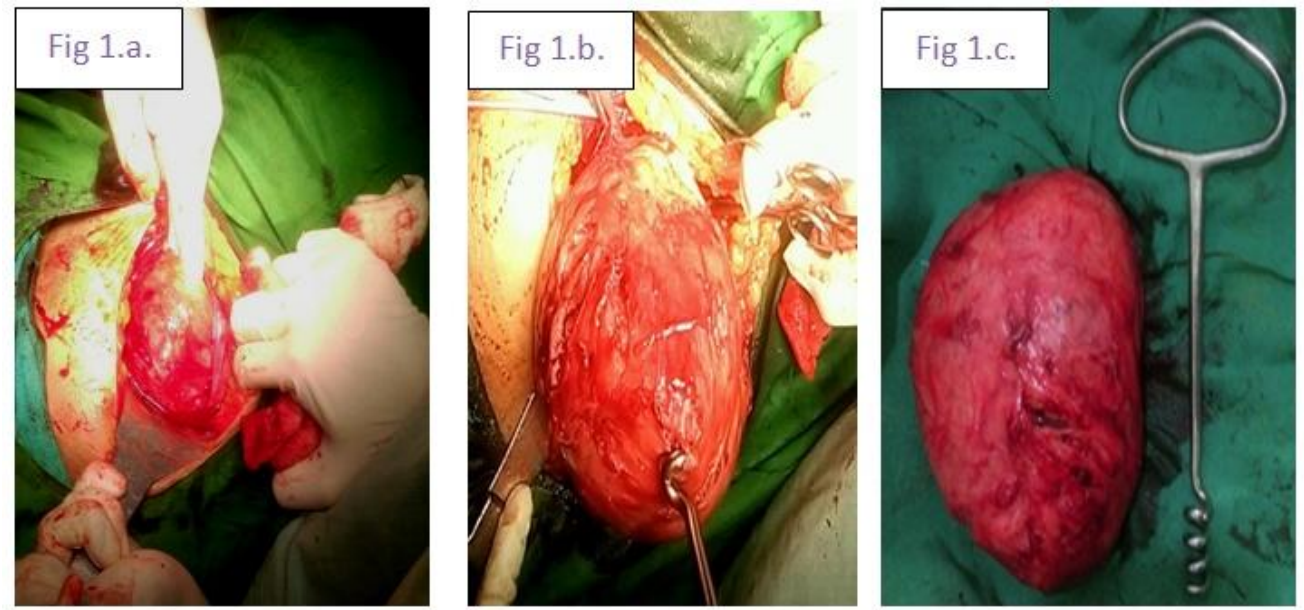

Fig 1.a: myoma jutting out from the uterine incision; $b$ : enucleation of myoma; c: myoma after enucleation.

Double layered closure of the caesarean incision with 1-0 Vicryl sutures was followed. High dose oxytocin was used intraoperatively and postoperatively in all cases. Some patients required additional uterotonic agents, intramyomal vasopressin injection and haemostatic sutures over the myoma bed. A single patient required bilateral uterine artery ligation for heamostasis. Blood loss was estimated from suction aspiration. Prophylactic antibiotics were administered to all the patients.

\begin{tabular}{|c|c|c|c|c|c|c|}
\hline Age/ Parity & $\begin{array}{l}\text { Risk factor/ } \\
\text { Comorbidity }\end{array}$ & $\begin{array}{l}\text { No and Location of } \\
\text { fibroids }\end{array}$ & Type Of CS & $\begin{array}{l}\text { Size of fibroids } \\
\text { removed }\end{array}$ & GA at CS & $\begin{array}{l}\text { Estimate } \\
\text { d blood } \\
\text { loss }\end{array}$ \\
\hline $34 \mathrm{yr} /$ Primi & $\begin{array}{l}\text { Gestational } \\
\text { hypertension }\end{array}$ & $\begin{array}{lr}\text { Left } & \text { lateral } \\
\text { endocervical } \\
\text { fibroid, } & \text { anterior } \\
\text { wall } & \text { submucous } \\
\text { fibroid } & \text { with } \\
\text { multiple } & \text { small } \\
\text { fibroids } & \\
\end{array}$ & Elective LSCS. & $\begin{array}{l}\text { Left rateral } \\
\text { endocervical fibroid } \\
13 \times 8 \mathrm{~cm} \text { anterior } \\
\text { wall submucous } \\
\text { fibroid } 5 \times 6 \mathrm{~cm}\end{array}$ & $\begin{array}{l}36 \text { weeks } 2 \\
\text { days }\end{array}$ & 1.2 litres \\
\hline 32 yr / Primi & -- & $\begin{array}{l}\text { Anterior wall } \\
\text { subserosal fibroid }\end{array}$ & Elective LSCS & $5 \times 5 \mathrm{~cm}$ & $\begin{array}{ll}38 & \text { weeks } 1 \\
\text { day }\end{array}$ & 1 litre \\
\hline 35 yr/ Primi & -- & $\begin{array}{l}\text { Left } \\
\text { fundolateralsuberou } \\
\text { s fibroid }\end{array}$ & Elective LSCS & $11 \times 8 \mathrm{~cm}$ & $\begin{array}{l}37 \text { weeks } 6 \\
\text { days }\end{array}$ & 1 litre \\
\hline $30 \mathrm{yr} /$ Primi & $\begin{array}{l}\text { Placenta previa } \\
\text { grade IV with } \\
\text { APH }\end{array}$ & $\begin{array}{ll}\text { Fundal subserosal } \\
\text { fibroid }\end{array}$ & $\begin{array}{l}\text { Emergency } \\
\text { LSCS }\end{array}$ & $8 \times 7 \mathrm{~cm}$ & $\begin{array}{l}36 \text { weeks } 6 \\
\text { days }\end{array}$ & 1.2 litres \\
\hline $\begin{array}{lll}38 \quad \text { yr } & / \\
\mathrm{G}_{2} \mathrm{P}_{1} \mathrm{~L}_{1} \mathrm{~A}_{0}\end{array}$ & $\begin{array}{l}\text { Breech with } \\
\text { PROM }\end{array}$ & $\begin{array}{l}\text { Anterior wall } \\
\text { intramural fibroid }\end{array}$ & $\begin{array}{l}\text { Emergency } \\
\text { LSCS }\end{array}$ & $10 \times 12 \mathrm{~cm}$ & $\begin{array}{l}36 \text { weeks } 3 \\
\text { days }\end{array}$ & $800 \mathrm{ml}$ \\
\hline $\begin{array}{l}34 \text { yr / } \\
\text { G3P0L0A2 }\end{array}$ & IVF pregnancy & $\begin{array}{l}\text { Three subserosal } \\
\text { fibroids; } 2 \text { anteriorwa } \\
\text { 1l, 1 posterior wall. }\end{array}$ & Elective LSCS & $\begin{array}{l}\text { Anterior subserosal } \\
\text { fibroids } 3 \times 2 \mathrm{~cm} \text { and } \\
3 \times 3 \mathrm{~cm} \text {, posterior } \\
\text { subseral fibroid } 2 \times 2 \\
\mathrm{~cm}\end{array}$ & $\begin{array}{l}38 \text { weeks } 3 \\
\text { days }\end{array}$ & $800 \mathrm{ml}$ \\
\hline
\end{tabular}

\section{Results}

The average age of the women included in the study was 33 years. The age, parity, and associated risk factors of the patients; size and location of the myomas; type of caesarean and intra-operative findings are summarised inTable1. Themyomasize varied from $5-13 \mathrm{~cm}$. Regarding intra-operative blood loss, 2 patients lost $800 \mathrm{ml}, 2$ patients lost around 1litre and remaining 2 patients lost around 1.2 litres of blood ,counting to an average of 1 litre blood loss. Intra-myomal vasopressin injection was used in one patient with multiple fibroids, largest been $13 \times 8 \mathrm{~cm}$ endocervical fibroid.A single patient required bilateral uterine artery ligation.None of the patients required blood transfusion or hysterectomy. Neonatal outcome was good in all the patients. The mean 
gestational age at delivery was 37.33 weeks (range 36-39 weeks). The 5 minute Apgar score was 9-10 in all the newborns with birth weights ranging from $2800-3250$ grams.

\section{Discussion}

One in ten of the women with pregnancy with myomawill have complications during pregnancy that are related to the myoma. A great majority of myomas associated with pregnancy remain asymptomatic and do not require treatment, with about $22-32 \%$ showing increased growth.[6] Larger fibroids $(>5 \mathrm{~cm})$ are more likely to grow during pregnancy and can cause miscarriages, preterm labour, , malpresentations, pressure symptoms, pain due to red degeneration, preterm premature rupture of membranes, obstructed labour, retained placenta, postpartum haemorrhage and uterine torsion.[6,20,21] Katz et al. found that $10-30 \%$ of women with myomas associated with pregnancy had complications as listedabove.[21] Caesarean section rates in women with myomas are higher, up to $73 \%$, mainly due to obstructed labour and malpresentations.[4]

The orthodox view of one of the pioneers of myomectomy in non-pregnant women, Bonney, is reflected in his writings: "It is tempting for the adventurous and sympathetic surgeon to condense the operation of lower segment Caesarean section and myomectomy into one undertaking and save his patient the ordeal of a second admission to hospital. This kindly but misguided policy we heartily deprecate." However, his pupils, Hawkins and Stallworthy, did advocate Caesarean myomectomy in selected cases, as in the incidence of anterior lower segment myomas on the proposed incision line.[22]

Exacoustos and Rosetti reported that in their series of 9 cases of Caesarean myomectomy, three were complicated by severe haemorrhage necessitating hysterectomy; hence, they recommended caution while making the decision to perform this procedure.[23]Some authors report a higher incidence of postpartum haemorrhage and puerperal sepsis if the fibroid is not removed at Caesarean section. $[4,5]$ In addition, the uterus in the immediate postpartum phase is better adapted physiologically to control haemorrhage than at any other stage in a woman's life; hence, it seems logical to perform Caesarean myomectomy.

The management of fibroids encountered at Caesarean section remains a therapeutic dilemma. Myomectomy during Caesarean section has traditionally been discouraged due to the risk of uncontrollable haemorrhage, unless the myoma is pedunculated ${ }_{-}^{8}$ Recent studies have described techniques to minimise blood loss at Caesarean myomectomy including uterine tourniquet, bilateral uterine artery ligation, and electrocautery. ${ }^{7}$ Several authors have now shown that in selected patients and in experienced hands, myomectomy at the time of caesarean section is a safe and effective procedure. ${ }^{3,7-18}$

In our study series, blood losswas less than $1.2 \mathrm{~L}$ of blood and there was no significant postoperative morbidity.Despite the majority of the patients having large myomas, no hysterectomy was required in any patient. The diagnosis fibroids was confirmed by the pathology reports. Myomectomy added 15-20 minutes to the operating time andthere was no significant postoperative complications or prolongation of hospital stay. None of the patients required blood transfusion or had postoperative sepsis. The limitation of this study is the small sample size.

\section{Conclusion}

Cesarean myomectomy is not as dangerous as it has been thought of for generations. The various measures that can be undertaken to minimise blood loss during caesarean myomectomy are electrocutery, uterotonic agents,tourniquet or bilateral uterine arterial ligation, pericervical tourniquet application, intraoperative vasopressin, stepwise devascularisation.

Patient selection is crucial in Caesarean myomectomy. Myomectomy for myomas approaching the fundus and ostia of the tubes should be avoided as it may lead to adhesions causing future fertility problems. Intramural myomectomy demands caution. Accessible subserosal or pedunculated fibroids and lower uterine segment fibroids obstructing delivery of the baby can be safely removed by experienced surgeons.

The message is that its time to recommend caesarean myomectomy with adequate expertise, proper patient selection and effective heamostsatic measures, which could also have a positive bearing on future reproductive outcomes.

\section{References}

[1]. Barbara L. Hoffman, John O. Schorge, Joseph I. Schaffer, Lisa M. Halvorson, Karen D. Bradshaw, F. Gary Cunningham et al Williams Gynecology, $2^{\text {nd }}$ ed. New York: Mc Graw Hill;2012.

[2]. Muram D, Gillieson MS, Walters JH. Myomas of the uterus in pregnancy: Ultrasonographic follow-up.Am J Obstet Gynecol. 1980;138:16-9.

[3]. Kaymak O, Ustunyurt E, Okyay RE, Kalyoncu S, Mollamahmutoglu. Myomectomy during Cesarean section. Int J Gynecol Obstet. 2005;89:90-3.

[4]. Hasan F, Armugam K, Sivanesaratnam V. Uterine leiomyomata in pregnancy. Int J Gynecol Obstet.1990;34:45-8.

[5]. Davis JL, Ray-Mazumder S, Hobel CJ, Baley K, Sassoon D. Uterine leiomyomas in pregnancy: A prospective study. Obstet Gynecol. 1990;75:41-4. 
[6]. Rosati P, Exacoustas C, Mancuso S. Longitudinal evaluation of uterine myoma growth during pregnancy.J Ultrasound Med. 1992;11:511-5.

[7]. Ortac F, Gungor M, Sonmezer M. Myomectomy during Cesarean section. Int J Gynecol Obstet.1999;67:189-90.

[8]. Roman AS, Tabsh KMA. Myomectomy at the time of Cesarean delivery: retrospective cohort study.BMC pregnancy and childbirth. 2004;4:14. doi: 10.1186/1471-2393-4-14

[9]. Sapmaz E, Celik H, Altungul A. Bilateral ascending uterine artery ligation vs. tourniquet use for haemostasis in Cesarean myomectomy: a comparison. J Reprod Med. 2003;48:950-4.

[10]. Cobellis L, Florio P, Stradella L, Lucia ED, Messalli EM, Petraglia F, et al. Electro-cautery of myomas during Cesarean section: two case reports. Eur J ObstetGynecolReprod Biol. 2002;102:98-9.

[11]. Burton CA, Grimes DA, March CM. Surgical management of leiomyoma during pregnancy. Obstet Gynecol. 1989;74:70.

[12]. Kwon SY, Kim TH, Jeong JH, Lee CN. Is myomectomy safe during Cesarean section? Korean J Perinatol. 2003;14:154-9.

[13]. Ehigiegba AE, Ande AB, Ojobo SI. Myomectomy during Cesarean section. Int J Gynecol Obstet.2001;75:21-5.

[14]. Ahikari S, Goswami S. Cesarean myomectomy: A study of 14 cases. J ObstetGynecol India.2006;56:486-8.

[15]. Umezurike C, Feyi-Waboso P. Successful myomectomy during pregnancy: A case report. Reprod Health. 2005;2:6.

[16]. Omar SZ, Sivanesaratnam V, Damodaran P. Large lower segment myoma-myomectomy at lower segment Cesarean section: A report of 2 cases. Singapore Med J. 1999;40:109-10.

[17]. Li H, Du J, Jin L, Shi Z, Liu M. Myomectomy during Cesarean section. ActaObstetGynecol Scand.2009;88:183-6.

[18]. Hassiakos D, Christopoulos R, Vitoratos N, Xarchoulakou E, Vaggos G, Papadrias K. Myomectomy during Cesarean section: a safe procedure? Ann N Y Acad Sci. 2006;1092:408-13.

[19]. Adesiyum AG, Ojabo A, Durosinlorun-Mohd A. Fertility and obstetric outcome after cesarean myomectomy. J ObstetrGynecol 2008;7:710-12.

[20]. Myerscough PR. Munro Kerr's Operative Obstetrics. 10th ed. London: Baillière Tindall Publications; 1982. Pelvic tumors. Other surgical complications in pregnancy, labor and the puerperium; pp. 203-411.

[21]. Katz VL, Dotters DJ, Droegemueller W. Complications of uterine leiomyomas in pregnancy. ObstetGynaecol. 1989;73:593-6.

[22]. Howkins J, Stallworthy J. Bonney's Gynaecological Surgery. 8th ed. London: Baillière Tindall Publications; 1974. p. 421.

[23]. Exacoustos C, Rosati P. Ultrasound diagnosis of uterine myomas and complications in pregnancy. Obstet Gynecol. 1993;82:97101. 